\title{
Promoting the Unity of Legal Education and Ideological and Political Education
}

\author{
Zhang Liying ${ }^{1}$; Zhang Yang ${ }^{2 *}$ \\ 1. Law School, Beihua University, Jilin, Jilin 13200; \\ 2. School of Information Technology and Media, Beihua University, Jilin, Jilin 132013 \\ *Corresponding author
}

Keywords: Legal education, Ideological and political education, Running the country in accordance with the law, Ruling the country by virtue.

\begin{abstract}
China's ideological and political education has a long history, but legal education has been developed only for a short time. During the "Cultural Revolution", China's legal construction was damaged. Enhancing legal education is imminent at present when running the country in accordance with the law and improving the socialist legal system are required. Integration of running the country in accordance with the law and ruling the country by virtue is to unify legal education and ideological and political education. Only when the two are unified, can the socialist political culture be constructed successfully.

China's ideological and political education has a long history, but legal education has been developed for not a long time. With the initiative of "running the country in accordance with the law, and constructing a socialist legal state", legal education is put on the agenda. Enhancing socialist legal construction and strengthening legal education are extremely urgent. Combining rule of virtue and law requests us to integrate legal education and ideological and political education and promote the organic unification of legal education and ideological and political education.
\end{abstract}

\section{Relationship between the science of law and ideological and political science}

Legal system refers to the law and system established by a ruling class according to their own willingness through a state political power to maintain the dictatorship of the class. All types of nations have their own legal system. Socialist legal system is the law and system built by socialist states in accordance with the will of the proletariat and the masses, and is an important tool to protect people, attack enemies, punish crimes, maintain social order, guard socialist economic foundation, promote the development of social productivity, and realize the historical task of people's democratic dictatorship. China transformed from a semi feudal and semi colonial society to socialist society with an imperfect legal system. Besides, in "ten chaotic years", the legal system was overridden rampantly, leading to lawlessness, little observation of laws, slack law enforcement and refraining from punishing law breakers, and meanwhile, resulting in people's weak understanding of law in general. In this case, enhancing socialist legal system construction and intensifying efforts to socialist legal education is very necessary.

The science of law and ideological and political science are independent subjects with close relation: first, in view of social governance, legal education and ideological and political education are two functions and methods to govern the society, and they are correlated, supplementary and irreplaceable. Law is led by ideological and political education, and ideological and political education is backed by law. If we fail to construct a good the legal system, the social order will be disordered, and ideological and political education will be failing. Social governance must attach equal importance to legal and ideological and political education. Second, viewed from the contents of subject, the science of law and ideological and political science are correlated and consistent in content. One important content of ideological and political education is legal education. However, 
in a society with perfect legal system, law must include the ideological and political education of a certain class into provisions to protect it. Therefore, ideological and political education must absorb the knowledge and theory of the science of law, and takes legal thought and relevant laws as its important contents to make the educated grasp necessary knowledge of laws, establish legal sense, and consciously respect justice and abide by the laws.

\section{Establishment and improvement of the Basis of Law}

\subsection{Evolution of the curriculum goal}

Basis of Law was generated in the context of nationwide education for law knowledge. Before the Central Committee of the Communist Party of China and the Sate Council transmitted the notice on Five Year Plan of Popularizing the Common Knowledge in Law to All Citizens (the First Five-Year Plan of Law Popularization), many of the delinquency were law-ignorant person who violated laws but did not understand laws. In October 1985, the Central Committee of the Communist Party of China issued the "Notice on Further Enhancing Teenager Education and Preventing Delinquency of Teenagers", requested to "vigorously popularize the common knowledge of laws, and make teenagers to culture a good habit of observing law and discipline", and proposed that universities should open legal education curriculum. In September 1986, the Ministry of Education of the PRC regulated in the "Notice on Opening 'Basis of Law' in Universities" that in accordance with the demand of the the Party Central Committee and NPC Standing Committee to implement the popularization of laws, the course that Basis of Law should be opened to college students. In 1987, the Ministry of Education of the PRC stipulated the teaching purpose and demands of Basis of Law in "Suggestions for the Construction of Ideological and Political Education Course in Colleges and Universities": to enable students to understand the basic viewpoints of Marxist jurisprudence, grasp the fundamental spirit and regulations of constitution and specialized laws, enhance legal sense and sense of social responsibility, and correctly utilize civil rights and obligations to adapt to the requirements of socialist legal system construction".

In 1995, the Ministry of Education of the PRC, the Comprehensive Treatment of Social Management Committee, and the Ministry of Justice of the PRC jointly issued the "Suggestions of Enhancing Legal Education in Schools" and further emphasized that "legal education in colleges and universities should take the cultivation of socialist legal sense of college students as the core". The goal was slightly higher than the Second Five-Year Plan of Law Popularization and accommodated to the Third Five-Year Plan of Law Popularization issued later. In 1998, the Propaganda Department of the Central Committee of the CPC and the Ministry of Education of PRC pointed out that "the 'Basis of Law' is mainly socialist legal education to help students grasp the basic viewpoints of Marxist jurisprudence, understand the basic spirit and provisions of constitution and relevant specified laws, enhance students' socialist legal sense and consciousness". In February 2003, the Ministry of Education of the PRC revised the basic requirements of "Two Courses" in colleges and universities.

The fundamental requirements for "Basis of Law" was "to enable college students understand the basic viewpoints of Marxist jurisprudence, grasp the basic spirit and contents of China's constitution and relevant laws, enhance legal consciousness, and improve legal quality". The goal requested to be based on "improving legal quality", which was obviously higher than the requirements of the "Fourth Five-Year" Plan of Law Popularization.

In February 2005, the Suggestions for Further Enhancing and Improving Ideological and Political Theoretical Course in Colleges and Universities issued by the Propaganda Department of the Central Committee of the CPC and the Ministry of Education of PRC integrated Ideological and Moral Cultivation with Basis of Law. The Implementation Plan issued in March emphasized that "ideological and moral cultivation and basis of law" focused on socialist moral and legal education, helped students enhance socialist legal sense, improve ideological and moral quality, and solve the practical problems encountered in growth. In 2010, the socialist legal concept was included into the textbook of Ideological and Moral Cultivation and Basis of Law. It is necessary to teach according to the content in Socialist Legal Concept when teaching "Chapter 7 Enhancing Legal Consciousness 
and Carrying Forward Legal Spirit".

In 2011, the Sixth Five-Year Plan of Law Popularization pointed out that the guiding ideology and primary objective was to fully carry out the fundamental strategy of running the country in accordance with the law and socialist political and cultural construction, insists on the integration of legal publicity and education and socialist core value system education, socialist legal concept education, socialist consciousness of citizenship education, and legal practice, deeply carry out legal publicity and education, promote rule of law, and vigorously carry forward socialist legal spirit. The primary objective of the "Sixth Five-Year" Plan of Law Popularization also points out the key teaching points for the teaching program of ideological and political education in universities.

\subsection{Constantly improving and developing teaching goals}

(1) Goal of imparting knowledge of laws

The goal is the necessary method to realize the latter two targets. From a historical perspective, China is weak in the foundation of democracy, so cultivation of legal consciousness, formation of legal concept, and improvement of legal quality must be based on the impartment of legal knowledge; from the perspective of epistemology, perfect legal knowledge is the premise for college students to establish scientific legal consciousness and cultivate good legal quality.

(2) Goal of enhancing legal consciousness

Cultivating legal consciousness is the core target of legal education. Legal consciousness is the general term of legal concept and sense, and is one of social consciousness, including views of the essence and function of laws, requirements and attitude to existing laws, evaluation, understanding and interpretation of law itself and application of law, and appraising whether people's behavior is legitimate. Perspectives on law, also called legal viewpoints, refers to the opinions and attitudes to laws; legal concept, also called legal sense, is the ideology to emphasize, abide by and consciously enforce laws. Basis of Law is an ideological and moral education course that takes the impartment of the fundamental theory and principle of laws as well as necessary legal basic knowledge as the means. Therefore, we should not only teach legal knowledge, but also cultivate students to trust and respect laws, make them establish scientific value rule of law, right sight and justice view, and set up correct legal consciousness.

(3) Goal of improving legal quality

Legal quality refers to the structure of mind and body with stable behavior internalized by absorbing human's existing achievements in legal civilization when people receive legal education, and is the outcome due to the joint effect of social environment, legal education and practice on the basis of innate genetic predisposition. Legal quality is an important part of the quality of contemporary college students. Therefore, we should take "high legal quality" as the fundamental goal of Basis of Law to cultivate students' theory accomplishment in Marxist jurisprudence and their legal ideation, improve their consciousness and ability of innovation of correctly recognizing and analyzing existing significant legal practice issues, enhance the immunity of frequent delinquency, official corruption and judicial corruption in the social transformation period; cultivate students' sound juridical personality, and make them take the law as the criterion to judge, restrain their behavior, treat others correctly, maintain the dignity of law consciously, protect the interests of the state and the people, and safeguard the stability of the state and the society.

Teaching legal knowledge, enhancing legal consciousness and improving legal quality are not only the goals of Basis of Law, but also the targets of China's legal education. In China's legal education, teaching legal knowledge is the basis; enhancing legal consciousness is necessary; improving legal quality is essential.

Legal education and ideological and political education are two important methods to improve the democratic and legal concept as well as ideological and moral quality of social members including college students, two significant means to guarantee social stability and two fundamental guarantees to promote the development of socialist market economy and economic prosperity. It is unrealistic and biased to just focus on ideological and political education one-sided rather than compensate with perfect and powerful legal education; it also unscientific and insipid to substitute ideological and political education with legal education purely. In the social regulation and control 
system, only by grasping two key links at the same time and cooperating orderly can successfully establish a socialist political culture and complete the historical mission of building a well-off society in an all-round way.

\section{References}

[1] Lei Yonggui. Study on Three Levels of the Education Goals of Basis of Law in Colleges and Universities [J]. Journal of Nantong Vocational University, 2006, (12).

[2] Xiao Xuezhen, Wu Xiancheng. Discussion of the Unified Relationship Between Democratic Legal Construction and Ideological and Political Work [J]. Journal of Keshan Teachers College, 2004, (3).

[3] Hou Yonglan. Problems and Introspection of Education of Basis of Law in Universities [J]. Journal of Jianghan University (Social Science), 2004 (6).

[4] Wu Jing. Dialectical unity relationship between legal education and ideological and political education in Higher Vocational Colleges. [J]. Legal system and economy (late). 2012(6).

[5] Liu Ying. Legal education in civic education and its value. [D]. Wuhan: Wuhan University of Technology. 2010.

[6] Chen Jie. Research on Legal Education of college students in China. [D].Shanghai: Fudan University. 2012. 